\title{
PERANAN POLITIK HUKUM INVESTASI DALAM PEMBANGUNAN EKONOMI INDONESIA
}

ALADIN SIRAIT

Email: aladin.sirait@gmail.com

\begin{abstract}
Abstrak
Sudah merupakan kodratnya bahwa manusia tidak bisa hidup sendiri,harus hidup bersama dalam hal suatu masyarakat yang terorganisir untuk mencapai tujuan bersama. Agar tujuan tersebut tercapai sebagaimana mestinya, dan dalam usaha tidak selalu benetur kepentingan, maka diperlukan suatu Hukum yang dijadikan sebagai alat untuk mengatur segala aktifitas manusia baik yang bergerak maupun tidak bergerak dalam masyarakat, begitu dunia investasi Indonesia sangat maju tetapi masih kendala dalam aturan sehingga tidak mempunyai efek dalam pembangunan ekonomi bangsa indonesia, kita bisa lihat banyak investor yang berinvestasi di indonesia tetapi banyak kendala yang dihadapi hal ini dikarenakan aturan dalam mengatur tentang pentingnya investasi untuk memajukan perekonomi bukan hanya di bidang infrastruktur tetapi pembangunan sumber daya ekonomi rakyat indonesia yang benar-benar bisa dinikmati oleh rakyat indonesia. Maka itu Industri hukum harus dijadikan sebagai terbosan dalam hukum investasi untuk pembangunan ekonomi bangsa indonesia sehingga amanah undang-undang dasar 1945 pasal 33 bisa diberuntuhkan untuk kemakmuran rakyat.
\end{abstract}

Kata kunci: Politik Hukum, Investasi, Pembangunan Ekonomi

\section{A. PENDAHUluan}

Istilah investasi berasal dari bahasa latin, yaitu investire (memakai), sedangkan dalam bahasa inggris disebut sebagai investment istilah hukum investasi berasal dari terjemahan bahasa inggris, yaitu investment of law. Dalam peraturan perundang-undangan tidak ditemukan pengertian hukum investasi. Untuk mengatahui arti dari hukum investasi ini, maka harus dicari pandangan para ahli dan kamus hukum. ${ }^{1}$

Para ahli dalam bidang investasi memiliki pandangan yang berbeda mengenai konsep teoritis tentang investasi, Fitzgerald mengartikan investasi adalah aktifitas yang berkaitan dengan usaha penarikan sumber dana yang dipakai untuk mengadakan barang modal pada saat sekarang, dan barang modal akan

1 Abdul Manan, Peranan Hukum Dalam Pembangunan Ekonomi, (Jakarta : Kencana Prenada Media Group, 2014), hlm, 75 
menghasilkan aliran produk baru dimasa yang akan datang, dalam defenisi ini investasi di kontruksikan sebagai sebuah kegiatan untuk menarik sumber dana yang digunakan untuk pemberian barang modal, dan barang modal tersebut menghasilkan produk baru. Dalam defenisi lain Kamaruddin Ahmad mengemukakan bahwa yang dimaksud dengan investasi adalah menempatkan uang atau dana dengan harapan untuk memperoleh tambahan atau keuntungan tertentu atas uang atau dana tersebut dalam defenisi ini investasi di fokuskan pada penempatan uang atau dana dengan tujuan untuk memperoleh keuntungan sebagai mana yang diharapkan. ${ }^{2}$

Dari berbagai pengertian investasi seperti tersebut diatas, ada perbedaan istilah dengan "penanaman modal" yang pada hakekatnya mempunyai arti yang sama. Dalam undang-undang Nomor 25 Tahun 2007 Tentang Penanman Modal (UUPM) dikemukakan bahwa penanaman modal adalah segala bentuk kegiatan penanaman modal, baik penanaman modal dalam negeri maupun penanaman modal asing, untuk melakukan usaha di wilayah republik indonesia. Dari pengertian ini dapat diketahui bahwa investasi dan penanaman modal adalah kegiatan yang dilakukan oleh seseorang atau bahan hukum, menyisihkan sebagian pendapatnyan agar dapat digunakan untuk melakukan suatu usaha dengan harapan pasa suatu waktu tertentu akan mendapat hasil. ${ }^{3}$

Untuk memhami secara utuh tentang Investasi di Indonesia, pertamatama perlu diketahui hakekat pembangunan ekonomi nasional ditinjau dari sudut pandang hukum, meski para ahli hukum memberikan uraian yang berbeda-beda mengenai hal tersebut, pendapat yang berkembang pada dasarnya memberikan pengertian pembangunan nasional maknanya kurang lebih sama. Pendapat Darji Darmodiharjo dan shidarta yang memberikan pengertian pembangunan nasional sebagai berikut: “

adapun pembangunan nasional itu sendiri pada hakikatnya merupakan pembangunan manusia indonesia sutuhnya dan pembangunan masyarakat indonesia seluruhnya, dengan pancasila sebagai dasar, tujuan dan pedomannya"4

2 Jonker Sihombing, Hukum Penanaman Modal di Indonesia, (Bandung : Alumni,2009), hlm, 45

${ }^{3}$ H.Salim HS, Penerapan Teori Hukum pada Penelitian Disertasi dan Tesis, KDT, Pers (Depok : Rajawali, 2017), hlm, 23

${ }^{4}$ Ibrahim,Johnny, Teori \& Metodologi Penelitian Hukum Normatif, (Malang: Bayumedia Publishing, 2006), hlm 34 
Dari pengertian pembangunan nasional sebagaimana yang disebutkan oleh Darji Darmodiharjo dan Shidarta diatas dapat disimpulkan bawah pembangunan nasional di Indonesia mempunyai dimensi yang sangat luar. Pembangunan nasional tidak hanya berkaitan dengan hal-hal yang bersifat nyata tetapi juga mencakup hal-hal yang tidak dapat dilihat secara nyata karena meliputi seluruh aspek kehidupan masyarakat Indonesia.

Satjipto Raharjo menyebutkan pembangunan nasional dengan versi yang sedikit berbeda walaupun maknanya kurang lebih sama. Ia menyatakan bahwa pembangunan nasional yang dilaksanakan bukan hanya dimaksudkan untuk melakukan perubahan-perubahan yang bersifat kuantitatif semata-mata, tetapi mencakup pula perubahan-perubahan yang bersifat kualitatif lebih lanjut Satjipto Raharjo menyebutkan

"pembangunan bukan merupakan suatu perubahan yang bersifat sepotong-potong, sekalipun misalnya kita dapat menunjukan Industrialisasi sebagai inti dari perubahan itu, tetapi ia pada akhirnya bukan hanya merupakan kasus penambahan jumlah industri secara kuantitatif. Dihubungkan dengan struktur masyarakat Industrialisasi ini mengundang terjadinya perubahan secara kualitatif". ${ }^{5}$

Untuk mewujudkan visi perekonomian yang maju, mandiri, dan mampu secara konkrit memperluas peningkatan kesejahteraan masyarakat harus berlandaskan pada prinsip-prinsip ekonomi yang menjunjung tinggi persaingan sehat dan keadilan, serta berperan aktif dalam perekonomian global dan regional dengan bertumpu pada kemampuan dan potensi bangsa.Dalam upaya mewujudkan pembangunan ekonomi ini sebagai tujuan Negara dalam pelaksanaannya telah direncanakan melalui suatu proses yang bertahap, terencana, terpadu dan berkesinambungan dengan dilandasi UU No.17 Tahun 2007 tentang Rencana Pembangunan Jangka Panjang Nasional Tahun 2007 (RPJPN 2005-2025). Di dalam Visi dan Misi RPJPN dinyatakan bahwa:

"Pembangunan bangsa Indonesia bukan hanya sebagai bangsa yang mandiri dan maju, melainkan juga bangsa yang adil dan makmur. Sebagai pelaksana dan penggerak pembangunan sekaligus objek pembangunan, rakyat mempunyai hak, baik dalam merencanakan, melaksanakan, maupun menikmati hasil pembangunan.

${ }^{5}$ Jimly Asshiddiqie, Konstitusi Ekonomi, (Jakarta: Kompas Media Nusantara, 2016), hlm 65 
Pembangunan"haruslah dilaksanakan dari rakyat, oleh rakyat dan untuk rakyat. Oleh karena itu masalah keadilan merupakan ciri yang menonjol pula dalam pembangunan nasional".

Sebagai tahapan pelaksanaan pembangunan ekonomi ini sebagaimana pada RPJM 2005-2019, menyangkut sarana dan prasarana yang dibutuhkan untuk pertumbuhan ekonomi, bidang energi menempati urutan strategis dan penting diantara bidang-bidang strategis lainnya jaringan transportasi (darat,laut dan udara) dan telematika.

Pembangunan ekonomi termasuk sarana dan prasarananya membutuhkan dana yang besar dengan penekanan,sedapat mungkin dengan prinsip kemandirian yaitu menggunakan dana yang dimiliki oleh bangsa Indonesia sendiri. Salah satu penyokong pembangunan ekonomi adalah Anggaran Pendapatan dan Belanja Negara (APBN) yang telah ditetapkan sebagai sumber sebagai dana untuk pembangunan nasional akan tetapi mengingat besarnya dana yang dibutuhkan dan dana APBN yang relatif terbatas dan apabila dana tidak mencukupi menimbulkan berisiko terhambatnya pembangunan yang berkesinambungan, oleh karena itu sumber-sumber pembiayaan lain baik itu swasta dalam negeri maupun sumber dari luar (asing).

\section{B. METODELOGI}

Penelitian ini akan dilakukan dengan mengambil studi khusus pada penanaman modal dalam Pembangunan Pembangkit Listrik Tenaga Air (PLTA) skala menengah (>10 MW) sebagai suatu model studi. Melalui penelitian ini diharapkan akan dapat diketahui dan dipetakan dengan jelas mengenai konsistensi, sinkronisasi dan harmonisasi undang-undang yang ada yaitu Undang-undang Nomor 25 Tahun 2007 tentang Penanaman Modal, UndangUndang Nomor 30 Tahun 2009 Tentang Ketenagalistrikan dan peraturanperaturan terkait secara vertikal, turunan dan horizontal sehingga dapat memberikan masukan atau kontribusi untuk pembaharuan Undang-undang penanaman modal dalam rangka mewujudkan nilai keadilan sosial berdasarkan falsafah Pancasila dan demokrasi ekonomi berdasarkan UUD 1945. Secara lebih praktis, merealisasikan regulasi penanaman modal dalam pembangunan Pembangkit Listrik Skala Menengah (>10 MW) yang secara konkrit dapat 
menjamin kepastian hukum dalam meningkatkan partisipasi masyarakat di bidang investasi. ${ }^{6}$

Penelitian ini mencakup Pasal 33 UUD 1945, Undang-Undang Penanaman Modal No.25 Tahun 2007, Undang-Undang Nomor 30 Tahun 2009 Tentang Kelistrikan, Perpres Nomor 76 dan 77 Tahun 2007 tentang DNI peraturan perundang-undangan serta instrumen/perangkat pelaksanaan yang berkaitan dengan penanaman modal pada Pembangunan Pembangkit Listrik skala menengah (lebih besar dari $10 \mathrm{MW}$ ) untuk dapat mengetahui lebih jauh mengenai konsistensi Undang-Undang Penanaman Modal, regulasi dan peraturanperaturan penanaman modal di dalam satu Pembangunan Pembangkit Listrik skala menengah (lebih besar dari $10 \mathrm{MW}$ ) khususnya yang menggunakan Sumber Daya Air (SDA) dan bagaimanakah dampak akibat adanya inkonsistensi dalam peraturan perundang-undangan terkait yang menjadi kesatuan hukum. Sehingga dengan demikian dapat dirumuskan suatu konsep penanaman modal atau suatu pola pendekatan yang dapat dipertimbangkan sebagai instrument perubahan atau upaya konsep hukum yang lebih berkeadilan sosial sesuai dengan demokrasi ekonomi pasal 33 UUD 1945 dan berdasarkan filsafat Pancasila dan UUD 1945 menuju kesejahteraan rakyat.

\section{PEMBAHASAN dan HASIL}

Konstitusi Indonesia adalah UUD 1945 sebagai hukum tertinggi, dan semua undang-undang di bawahnya harus mengacu kepada UUD 1945. UndangUndang yang tidak sesuai dengan UUD 1945, Mahakamah Konstitusi berhak dan berwenang mengadakan judicial review terhadap undang-undang tersebut.

Konsekuensi dari Pancasila sebagai Landasan Ideologi dan landasan Falsafah hukum dan UUD 1945 sebagai Hukum Dasar Negara Republik Indonesia, adalah bahwa semua hukum maupun undang-undang harus sesuai dengan Pancasila dan UUD 1945 dan nilai-nilai yang terkandung di dalamnya. Dalam konteks tulisan, hukum penanaman modal UU No 25 Tahun 2007 dan peraturan perundang-undangan yang terkait sebagai suatu kesauan sistem hukum harus sesuai dengan Pancasila dan UUD 1945 dan nilai-nilai yang terkandung di dalamnya. ${ }^{7}$

${ }^{6}$ Ibrahim,Johnny, Teori \& Metodologi Penelitian Hukum Normatif, (Malang: Bayumedia Publishing,2006), hlm, 70

${ }^{7}$ Undang-Undang Nomor 25 Tahun 2007, Tentang Penanaman Modal 
Nilai-nilai yang terkandung di dalam pancasila dan UUD 1945 yaitu keadilan sosial dan demokrasi ekonomi tidak boleh terputus atau menyimpang pada undang-undang maupun peraturan di bawahnya, karena apabila demikian maka tujuan dari pembentukan undang-undang untuk keadilan sosial menuju kesejahteraan rakyat tidak akan tercapai. Konsistensi materil dari undang-undang sesuai dengan struktur tertinggi sampai terendah menjadi syarat yang harus dipenuhi untuk keberhasilan hukum yang menyangkut peraturan perundangundangan tentang penanaman modal dan regulasi terkait sampai pada peraturan pelaksanaannya secara konkrit. ${ }^{8}$

Hukum Penanaman Modal dan perangkat peraturan maupun regulasi berkaitan secara materi merupakan bahasan utama untuk melihat apakah Undang-Undang Penanaman Modal No.25 Tahun 2007 secara konsisten telah sesuai dengan Pasal 33 UUD 1945 dan selanjutnya meneliti konsistensinya sampai pada Perpres No.76, Perpres No.77, sampai regulasi Badan Koordinasi Penanaman Modal (Perka-BKPM).

\section{Konsepsi Hukum Indonesia dan Pengaruh Rechsstatt dan The Rule of Law}

Di dalam khazanah ilmu hukum ada dua istilah yang diterjemahkan secara sama ke dalam bahasa Indonesia menjadi negara hukum yakni Rechtsstaat dan the Rule of Law.Meskipun terjemahannya ke dalam bahasa Indonesia sama-sama negara hukum, sebenarnya ada perbedaan antara Rechtsstaat dan the Rule of Law.Sebagaimana diidentifikasi ol Roscoe Pound, Rechtsstaat memiliki karakter administratif sedangkan the Rule of Law berkarakter yudisial.

Berbagai doktrin yang menunjukkan cirri-ciri dari suatu Negara hukum pertama sekali muncul dan berkembang di Negara yang menganut budaya hukum Anglo Saxon dengan sebutan Rule of Law dan Negara-negara yang menganut sistem hukum Eropa Kontinental menyebutnya dengan istilah Rechtsstaat.

Menurut Frederich Julius Stahl ahli hukum dari kalangan hukum Eropa Kontinental yang pertama sekali memberikan ciri-ciri Rechstaat meliputi sebagai berikut :

a. Hak Asasi manusia

8 Sri Redjeki Hartono, Hukum Ekonomi Indonesia, (Malang : Bayumedia Publising, 2007), hlm 50 
b. Pemisahan atau pembagian kekuasaan trias politica untuk menjamin hak asasi manusia.

c. Pemerintahan berdasarkan peraturan-peraturan; dan

d. Peradilan administrasi dalam perselisihan.

Di dalam tradisi hukum Eropa Kontinental ini, konsepnya sangat mengandalkan kepastian hukum yang terkodifikasi dalam satu himpunan. Kepastian hukum (legal certainty) merupakan istilah dari daratan Eropa, yang menjadi prinsip umum yang melandasi national legal system di sebagian besar Negara Eropa.

\section{Peranan Hukum Dalam Pembangunan Ekonomi}

Dalam sebagian besar masyarakat demokratis modern, peranan ahli hukum sangat penting, bahkan beberapa negara (seperti Amerika Serikat) sangat menonjol. Penyebabnya sebagian besar karena suatu konstitusi dan tertib hukum yang demokratis - apapun perbedaan-perbedaan yang ada di antara berbagai bentuk demokratis - didasarkan pada keseimbangan antara fungsi dan kekuatan yang sangat pelik. Hal ini menjadikan pentingnya peranan ahli hukum sebagai orang terlatih dalam menjaga keseimbangan di atas. Namun hal ini juga berkaitan dengan kenyataan bahwa dalam masa pembentukan demokrasi modern, khususnya sepanjang abad kesembilanbelas dan awal abad keduapuluh kebijaksanaan yang menonjol dalam bidang ekonomi adalah laissez faire, dimana usaha swasta sebagai alat dan promotor utama kegiatan ekonomi dan pengembangannya. Fungsi negara tetap terbatas pada bidang pertahanan, masalah luar negeri, dan kegiatan administratif serta kepolisian, sedangkan arus utama kehidupan ekonomi dan sosial mengalir melalui saluran-saluran swasta. Proses yang dimulai di dunia Barat pada abad kesembilanbelas dan terus meningkat dengan pesat pada abad keduapuluh, adalah perubahan dari masyarakat laissez faire, masyarakat perdagangan menjadi masyarakat sejahtera. Tingkat perencanaan, kewajiban sosial bersama dan Perusahaan Negara semakin bertambah. Keadaan ini membuat para ahli hukum tidak siap, baik secara mental maupun teknis. Memang menarik, tetapi tidak terlalu mengherankan bahwa analisa mengenai dampak dari ideologi perencanaan dan perundang-undangan kesejahteraan umum, terutama di dunia Anglo Amerika, sudah hampir tidak diakui.

Dalam perkembangan ekonomi suatu negara, kedudukan dan peranan hukum tentu dapat dianggap sangat penting. Bahkan Jean Jecques Rousseau pada 1755, dalam bukunya A Discourse on Political Economy, sudah menguraikan keterkaitan antara hukum dan ekonomi. Kata ekonomi itu 
sendiri berasal dari "oikos" yang berarti rumah tangga, dan "nomos" yang berarti hukum. Karena itu menurut Rosseau, "Only the wise and legitimate government of the house for the common good of the whole family. The meaning of the term was then extended to the government of that great family, the State." ${ }^{9}$

Amerika Serikat, sebagai negara yang menganut paham pasar bebas dengan tradisi hukum common law - misalnya, selama beberapa dasawarsa terakhir dikenal sangat produktif membuat undang-undang, dalam kurun waktu tahun 1970-an dan 1980-an, jumlah undang-undang yang ditetapkan di Amerika Serikat yang menganut tradisi common law justru jauh lebih banyak dibandingkan dengan jumlah undang-undang yang dibuat dan ditetapkan di negara-negara Eropa Barat yang menganut tradisi civil law. Artinya, kebutuhan akan regulasi oleh negara-negara tidak saja berkembang dikalangan negaranegara intervensionis seperti negara-negara sosialis dan komunis, tetapi juga di lingkungan negara-negara liberal barat yang menerapkan sistem ekonomi pasar. Alan Brudner, dalam Constitusional Goods, juga menguraikan mengenai hak-hak ekonomi yang diatur dalam berbagai peraturan perundang-undangan. Perlindungan hak-hak sosial dan ekonomi merupakan salah satu hal yang dipandang sangat penting di Amerika Serikat. ${ }^{10}$

Hal tersebut juga menunjukkan bahwa betapapun bebasnya dinamika perekonomian pasar hendak dikembangkan, tetap saja diperlukan intervensi negara dalam bentuk regulasi dan perizinan yang sangat berpengaruh dalam proses pembangunan ekonomi dan pengendalian pasar bebas. Pengaturanpengaturan yang demikian diperlukan dalam rangka jaminan sistem rujukan bersama antara pemangku kepentingan (stake-holders) dalam dinamika ekonomi pasar. Trias politika "state", "civil society", dan "market" dengan norma-norma hukum yang berlaku di dalamnya secara sendiri-sendiri membutuhkan pengaturan yang lebih luas oleh negara sebagai dirigent dalam dinamika perkembangan kegiatan perekonomian dalam masyarakat. Peraturan-peraturan resmi yang diberlakukan untuk umum itu tentu diharapkan berisi keadilan yang pasti, kepastian yang adil, dan kebergunaan. Dengan kepastian yang adil, keadilan yang pasti, dan kebergunaan itulah hukum dapat menjamin kebebasan yang teratur dalam dinamika perekonomian, sehingga pada gilirannya dapat membawa kesejahteraan bersama dalam kehidupan masyarakat.

${ }^{9}$ Mudrajad Kuncoro, Masalah, Kebijakan, dan Politik: Ekonomika Pembangunan, (Jakarta: Erlangga, 2010), hlm 30

${ }^{10}$ ibid 
Tanpa kepastian hukum (certainty), perekonomian tidak akan menumbuhkan kebebasan yang sehat dan berkeadilan adil; dan tanpa kebergunaan (utility), perekonomian tidak akan membawa kesejahteraan dan kedamaian. Karena pada akhirnya hukum itu sendiri haruslah membawa kehidupan bersama kepada kesejahteraaan dan kedamaian hidup bersama. Jadi, perizinan tetap diperlukan oleh setiap negara tanpa mengenal sistem pemerintahan dan sistem ekonominya, dalam upaya mengendalikan perdagangan dan perekonomian negaranya. Dengan demikian hukum dapat menjadi alat dalam memajukan perekonomian suatu bangsa dalam rangka mensejahterakan masyarakatnya, asalkan dilaksanakan secara adil dan konsisten serta dapat memberikan kepastian hukum bagi masyarakat. Sebaliknya hukum juga dapat menjadi penghambat kemajuan perekonomian bila pengaturannya dibuat secara tidak adil dan tidak konsisten, sehingga tidak tercipta kepastian hukum. ${ }^{11}$

Oleh karena itulah, peranan hukum penanaman modal sebagaimana telah diundangkan dalam Undang-Undang No. 25 Tahun 2007 tentang Penanaman Modal sebagai pengganti dari Undang-Undang No.1 Tahun 1967, merupakan kebijakan untuk mempercepat pembangunan ekonomi nasional melalui peningkatan penanaman modal guna mengolah potensi ekonomi menjadi kekuatan riil dengan menggunakan modal yang berasal baik dari dalam negeri maupun dari luar negeri. UU Penanaman Modal ini diciptakan untuk memberi kepastian hukum berusaha di Indonesia bagi penanam modal baik domestik maupun asing secara adil. Kepastian hukum berusaha secara adil ini diharapkan akan memberi kebergunaan atau kemanfaatan (utility) bagi peningkatan kesejahteraan masyarakat Indonesia. Kesejahteraan masyarakat ini merupakan cita-cita bangsa Indonesia yang telah ditetapkan dalam mukadimah dan batang tubuh UUD 1945 khususnya Pasal 33. ${ }^{12}$

Untuk itu, Undang-Undang Penanaman Modal tersebut harus dapat menciptakan iklim yang kondusif bagi penanaman modal. Sebab, penanaman modal merupakan kegiatan yang mengandung risiko, baik risiko yang berkaitan dengan nilai riil (real value) dari modal yang akan ditanamkan, maupun risiko yang berkaitan dengan ketakpastian apakah akan mendapatkan

11 Sri Redjeki Hartono, Hukum Ekonomi Indonesia, (Malang : Bayumedia Publising, 2007), hlm 87

${ }^{12}$ Soerjono Soekanto, Pengantar Penelitian Hukum, Cet.3. - (Jakarta: Penerbit Universitas Indonesia (UI-Press), 1986), hlm, 98 
kembali modal yang telah ditanamkannya sebagaimana yang diperkirakan semula.

Tentang tujuan hukum,pertama teori etis, hukum semata-mata bertujuan keadilan. Isi hukum ditentukan oleh keyakinan kita yang etis tentang adil dan tidak. Kedua, teori utilistis. Menurut teori ini, hukum ingin menjamin kebahagiaan yang terbesar bagi kemanusiaan dalam jumlah yang sebanyak-banyaknya (the greatest of the greatest number). Pada hakikatnya menurut teori ini tujuan hukum adalah manfaat dalam menghasilkan kesenangan atau kebahagiaan yang terbesar bagi jumlah orang yang terbanyak. Ketiga, teori campuran. Menurut Mochtar Kusumaatmadja, tujuan pokok dan pertama dari hukum adalah ketertiban. Kebutuhan akan ketertiban ini syarat pokok (fundamental) bagi adanya suatu masyarakat manusia yang teratur. Di samping tercapainya keadilan yang berbeda-beda isi dan ukurannya menurut masyarakat dan zamannya. Tujuan hukum ini hanya dapat tercapai bila hukum tersebut dilaksanakan dan ditegakkan secara adil..$^{13}$

Hukum berfungsi sebagai perlindungan kepentingan manusia. Agar kepentingan manusia terlindungi hukum harus dilaksanakan. Pelaksanaan hukum dapat berlangsung secara normal, damai, tetapi dapat terjadi juga karena pelanggaran hukum. Dalam hal ini hukum yang telah dilanggar itu harus ditegakkan. Melalui penegakan hukum inilah hukum ada tiga unsur yang selalu harus diperhatikan, yaitu: kepastian hukum (Rechtssicherheit), kemanfaatan (Zweckmassigkeit), dan Keadilan (Gerechtigkeit).

\section{URGENSI PEMBAHARUAN INVESTASI INDONESIA}

Era saat ini banyak orang memiliki kebutuhan dan keinginan yang sangat banyak. Kebutuhan dan keinginan semakin sulit untuk dibedakan karena tuntutan zaman yang semakin berkembang. Gaya hidup yang semakin kompleks pun membuat orang memiliki banyak tuntutan guna menunjang gaya hidupnya. Untuk memenuhi semua tuntutan tersebut tentu tidaklah cukup dengan mengandalkan gaji atau uang jajan yang diberikan orang tua. Untuk itu, penting untuk mencari cara untuk mendayagunakan uang yang kita miliki agar dapat memenuhi segala macam kebutuhan dan keinginan yang ada. Salah satu cara untuk mendayagunakan uang yang kita miliki adalah dengan melakukan investasi.

${ }^{13}$ ibid 
Dewasa ini bangsa indonesia berada pada nuansa waktu yang penting dalam rangka menyosong masa depan yang lebih sejahtera. Satu waktu yang merupakan titik balik reformasi yang telah berjalan hampir 22 tahun tidak balik tersebut tidak kembali pada keadaan, perilaku, dan kerangka berpikir lama, tetapi untuk selalu melakukan koreksi dan evaluasi atas sasaran masa depan yang lebih baik, dari tidak balik tersebut akan menjadi tidak tolak untuk menyosong kualitas bangsa dan negara yang lebih bermartabat dan berkualitas dalam menghadapi persaingan global dengan bangsa di dunia.

Masa depan jauh lebih penting dari pada hari ini dan masa depan lalu tetapi kita perlu belajar dan berkaca dari masa lalu agar tidak membuat kesalahan yang sama. Masalah adalah pengalaman untuk memperbaiki prestasi di masa depan, kesejahteraan bangsa dan negara menjadi tujuan bersama.

Salah satu teori ekonomi pembangunan yang sampai sekarang masih digunakan adalah teori Tabungan dan Investasi oleh Harrod-Domar. Dalam teori ini mencapai kesimpulan bahwa pertumbuhan ekonomi ditentukan oleh tingginya tabungan dan investasi. Kalau tabungan dan investasi rendah maka pertumbuhan ekonomi suatu Negara juga akan rendah. Masalah pembangunan pada dasarnya merupakan masalah menambahkan investasi modal, masalah keterbelakangan adalah masalah kekurangan modal. Kalau ada modal dan modal itu diinvestasikan hasilnya adalah pembangunan ekonomi.Dewasa ini hampir di semua negara, khususnya negara berkembang membutuhkan modal asing. Modal asing itu merupakan suatu hal yang semakin penting bagi pembangunan suatu negara. Sehingga kehadiran investor asing nampaknya tidak mungkin dihindari. Yang menjadi permasalahan bahwa kehadiran investor asing ini sangat dipengaruhi oleh kondisi internal suatu negara, seperti stabilitas ekonomi, politik negara, penegakan hukum. Penanaman modal memberikan keuntungan kepada semua pihak, tidak hanya bagi investor saja, tetapi juga bagi perekonomian negara tempat modal itu ditanamkan serta bagi negara asal para investor. Pemerintah menetapkan bidang-bidang usaha yang memerlukan penanaman modal dengan berbagai peraturan. Selain itu, pemerintah juga menentukan besarnya modal dan perbandingan antara modal nasional dan modal asing. ${ }^{14}$

${ }^{14}$ M. Irsan Nasarudin dan Indra Surya, Aspek Hukum Pasar Modal Indonesia, Cet. 1 - (Jakarta: Kencana, 2004), hl, 34 


\section{KEBIJAKAN INVESTASI DITINJAU DARI SEGI POLITIK HUKUM}

Pengaturan tentang kegiatan penanaman modal di Indonesia diatur dalam Undang-Undang No. 25 Tahun 2007 tentang Penanaman Modal. Dalam Pasal 3 ayat (1)huruf a, disebutkan bahwa kegiatan penanaman modal diselenggarakan berdasarkan asas kepastian hukum. Sementara itu yang dimaksud dengan "asas kepastian hukum" adalah asas dalam negara hukum yang meletakkan hukum dan ketentuan peraturan perundang-undangan sebagai dasar dalam setiap kebijakan dan tindakan dalam bidang penanaman modal.2 Dalamkonteks ini yang dimaksud dengan kepastian hukum adalah adanya konsistensi peraturan dan penegakan hukum di Indonesia. Konsistensi peraturan ditunjukkan dengan adanya peraturan yang tidak saling bertentangan antara satu peraturan dengan peraturan yang lain, dan dapat dijadikan pedoman untuk suatu jangka waktu yang cukup, sehingga tidak terkesan setiap pergantian pejabat selalu diikuti pergantian peraturan yangbisa saling bertentangan. Penjelasan Pasal 12 ayat (1) menyebutkan, bahwa bidang usaha atau jenis usaha yang tertutup dan yang terbuka dengan persyaratan ditetapkan melalui Peraturan Presiden disusun dalam suatu daftar yang berdasarkan standar klasifikasi tentang bidang usaha atau jenis usaha yang berlaku di Indonesia, yaitu Klasifikasi Baku Lapangan Usaha Indonesia (KBLI)

Pasal 12 ayat (2) menetapkan, bahwa bidang usaha yang tertutup bagi penanaman modal asing adalah:

a) Produksi senjata, mesiu, alat peledak, dan peralatan perang; dan

b) Bidang usaha yang secara eksplisit dinyatakan tertutup berdasarkan undang-undang. Dalam penjelasannya yang dimaksud dengan "alat peledak" adalah alat yang digunakan untuk kepentingan pertahanan dan keamanan. ${ }^{15}$

Ayat (3) pasal ini menyatakan, bahwa Pemerintah berdasarkan Peraturan Presiden menetapkan bidang usaha yang tertutup untuk penanaman modal, baik asing maupun dalam negeri, dengan berdasarkan kriteria kesehatan, moral, kebudayaan, lingkungan hidup, pertahanan dan keamanan nasional, serta kepentingan nasional lainnya. Selanjutnya ayat (4) menjelaskan Kriteria dan persyaratan bidang usaha yang tertutup dan yang terbuka dengan persyaratan serta daftar bidang usaha yang tertutup dan yang terbuka dengan persyaratan masing-masing akan diatur dengan Peraturan Presiden. Pasal 12

\footnotetext{
${ }^{15}$ ibid
} 
ayat (5) menyatakan Pemerintah menetapkan bidang usaha yang terbuka dengan persyaratan berdasarkan kriteria kepentingan nasional, yaitu perlindungan sumber daya alam, perlindungan, pengembangan usaha mikro, kecil, menengah, dan koperasi, pengawasan produksi dan distribusi, peningkatan kapasitas teknologi, partisipasi modal dalam negeri, serta kerja sama dengan badan usaha yang ditunjuk Pemerintah. Sebagai pelaksanaan ketentuan-ketentuan tersebut di atas Pemerintah telahmengeluarkan, Peraturan Presiden. Pertama, Peraturan Presiden No. 76 Tahun 2007tentang Kriteria dan Persyaratan Penyusunan Bidang Usaha Yang Tertutup dan BidangUsaha Yang Terbuka Dengan Persyaratan Di Bidang Penanaman Modal. Kedua,Peraturan Presiden No. 77 Tahun 2007 Tentang Daftar Bidang Usaha Yang Tertutupdan Bidang Usaha Yang Terbuka dengan Persyaratan Di Bidang Penanaman Modal jo.Peraturan Presiden No. 111 Tahun 2007 tentang Perubahan Atas Peraturan Presiden No.77 Tahun 2007 Tentang Daftar Bidang Usaha Yang Tertutup dan Bidang Usaha Yangerbuka dengan Persyaratan Di Bidang Penanaman Modal Pasal 13 ayat (1) menyatakan Pemerintah wajib menetapkan bidang usaha yang dicadangkan untuk usaha mikro, kecil, menengah, dan koperasi serta bidang usaha yang terbuka untuk usaha besar dengan syarat harus bekerja sama dengan usaha mikro, kecil, menengah, dan koperasi. Pasal 14 menyebutkan setiap penanam modal berhak mendapat:

a. kepastian hak, hukum, dan perlindungan;

b. informasi yang terbuka mengenai bidang usaha yang dijalankannya;

c. hak pelayanan; dan

d. berbagai bentuk fasilitas kemudahan sesuai dengan ketentuan peraturan perundangundangan

Pasal 15 menetapkan setiap penanam modal berkewajiban:

a. menerapkan prinsip tata kelola perusahaan yang baik;

b. melaksanakan tanggung jawab sosial perusahaan;

c. membuat laporan tentang kegiatan penanaman modal dan menyampaikannya kepadaBadan Koordinasi Penanaman Modal;

d. menghormati tradisi budaya masyarakat sekitar lokasi kegiatan usaha penanamanmodal; dan

e. mematuhi semua ketentuan peraturan perundang-undangan.

Pasal 16 undang-undang ini mengatur tentang tanggung jawab penanam modal,dimana setiap penanam modal bertanggung jawab :

a. menjamin tersedianya modal yang berasal dari sumber yang tidak bertentangandengan ketentuan peraturan perundang-undangan; 
b. menanggung dan menyelesaikan segala kewajiban dan kerugian jika penanam modalmenghentikan atau meninggalkan atau menelantarkan kegiatan usahanya secarasepihak sesuai dengan ketentuan peraturan perundang-undangan;

c. menciptakan iklim usaha persaingan yang sehat, mencegah praktik monopoli, dan hallain yang merugikan negara;

d. menjaga kelestarian lingkungan hidup;

e. menciptakan keselamatan, kesehatan, kenyamanan, dan kesejahteraan pekerja; dan

b. mematuhi semua ketentuan peraturan perundang-undangan

Biasanya orang hanya melihat dan bahkan terlalu sering mengidentikan hukum dengan peraturan hukum atau/bahkan lebih sempit lagi, hanya dengan undang - undang saja. Padahal, peraturan hukum hanya merupakan salah satu unsu saja dari keseluruhan sistem hukum, yang terdiri dari 7 (tujuh) unsur sebagai berikut :

a. asas-asas hukum (filsafah hukum)

b. peraturan atau norma hukum, yang terdiri dari :

1. Undang-undang

2. peraturan-peraturan pelaksanaan undang-undang

3. yurisprudensi tetap (case law)

4. hukum kebiasaan

5. konvensi-konvensi internasional

6. asas-asas hukum internasional

c. sumber daya manusia yang profesional, bertanggung jawab dan sadar hukum

d. pranata-pranata hukum

e. lembaga-lembaga hukum termasuk :

1. struktur organisasinya

2. kewenangannya

3. proses dan prosedur

4. mekanisme kerja

f. sarana dan prasarana hukum, seperti ;

1. furnitur dan lain-lain alat perkantoran, termasuk komputer dan sistem manajemen perkantoran

2. senjata dan lain-lain peralatan (terutama untuk polisi)

3. kendaraan

4. gaji 


\section{5. kesejahteraan pegawai/karyawan}

6. anggaran pembangunan, dan lain-lain

g. budaya hukum, yang tercermin oleh perilaku para pejabat (eksekutif, legislatif maupun yudikatif), tetapi juga perilaku masyarakat (termasuk pers), yang di Indonesia cenderung menghakimi sendiri sebelum benarbenar dibuktikan seorang tersangka atau tergugat benar-benar bersalah melakukan suatu kejahatan atau perbuatan tercela. Maka sistem hukum terbentuk oleh sistem interaksi antara ketujuh unsur di atas itu, sehingga apabila salah satu unsurnya saja tidak memenuhi syarat, tentu seluruh sistem hukum tidak akan berjalan sebagaimana mestinya. Atau apabila salah satu unsurnya berubah, maka seluruh sistem dan unsurunsur lain juga harus berubah. Dengan kata lain : perubahan undangundang saja tidak akan membawa perbaikan, apabila tidak disertai oleh perubahan yang searah di dalam bidang peradilan, rekruitmen dan pendidikan umum, reorganisasi birokrasi, penyelarasan proses dan mekanisme kerja, modernisasi segala sarana dan prasarana serta pengembangan budaya dan perilaku hukum masyarakat yang mengakui hukum sebagai sesuatu yang sangat diperlukan bagi pergaulan dan kehidupan bermasyarakat dan bernegara yang damai, tertib dan sejahtera.

\section{KESIMPULAN}

Pertumbuhan ekonomi pada zaman sekarang ini berdampak pada kehidupan penduduk suatu negara. Semuanya ini berpengaruh pada kesejahteran rakyat banyak. Penguatan peran dan kelembagaan pemerintah sangat penting untuk mendukung keberhasilan kebijakan investasi. Karena dengan kebijakan yang dibuat harus bisa menghadirkan kenyamanan bagi semua pihak sehingga tidak menggangu stabilitas keamanan pada saat investor sudah menanamkan modalnya.

Pemanfaatan sumber daya Manusia dan sumber daya alam yang terbatas diperlukan suatu aturan hukum yang mengatur tentang pentingnya investasi untuk pembangunan ekoonmi untuk kepentingan secara umum dan kemajuan bangsa, hal ini sangat penting sehingga semua kepentingan masyarakat dan kepentingan para investor yang difasilitasi oleh pemerintah dengan aturan hukum yang jelas. 
dalam menjalankan sistem pemerintahan yang berbasis untuk kepentingan masyarakat maka diperlukan investasi yang bergerak disegala bidang diutamakan untuk kepentingan negara, agar semua sektor yang menjanjikan keuntungan dalam berinvestasi bisa dimanfaatkan dengan baik untuk kepentingan negara dan kemakmuran rakyat, sesuai dengan amanah Undangundang Dasar 1945 Pasal 33 yang berbunyi bumi, air dan kekayaan alam didalamnya dikelolah oleh negara untuk kemakmuran rakyat.

Apabila semuanya dijalankan dengan regulasi yang didalamnya memuatkan pasal-pasal tentang pentingnya Investasi untuk pembangunan Ekonomi bangsa Indonesia sehingga semua pihak bisa menerima hal tersebut jadinya potensi konflik antara investor, pemerintah dan rakyat bisa diredam dengan regulasi yang benar-benar mengakomodir semua kepentinga.

Tentu dalam penulisan Jurnal Ilmiah ini masih banyak kekurangan dalam penulisan tersebut diharapkan bagi pembaca untuk bisa memberikan koreksi yang bersifat kronstrukitf sehingga penulis bisa memperbaiki. 


\section{DAFTAR PUSTAKA}

Abdul Manan, Peranan Hukum Dalam Pembangunan Ekonomi, Jakarta : Kencana Prenada Media Group, 2014

Jonker Sihombing, Hukum Penanaman Modal di Indonesia, Alumni, Bandung : 2009

H.Salim HS, Penerapan Teori Hukum pada Penelitian Disertasi dan Tesis, KDT, Rajawali Pers Depok, 2017

Ibrahim,Johnny, Teori \& Metodologi Penelitian Hukum Normatif, Bayumedia Publishing,Malang, 2006

Jimly Asshiddiqie, Konstitusi Ekonomi, Jakarta: Kompas Media Nusantara, 2016

Miriam Budiardjo, Dasar-Dasar Ilmu Politik, Edisi revisi,Cetakan 10, Agustus 2014, @2008 Penerbit PT.Gramedia Pustaka Utama.

Murdifin Haming \& Salim Basalamah dalam Jonker Sihombing, Hukum Penanaman Modal di Indonesia, Bandung: Alumni, 2009

M. Irsan Nasarudin dan Indra Surya, Aspek Hukum Pasar Modal Indonesia, Cet. 1 Jakarta: Kencana, 2004

Mudrajad Kuncoro, Masalah, Kebijakan, dan Politik: Ekonomika Pembangunan, Jakarta: Erlangga, 2010

Mochtar Kusumaatmadja, Konsep-konsep Hukum Dalam Pembangunan, Bandung: Alumni, 2011

Mohammad Hatta, Demokrasi Kita, Sega Arsy, Bandung,2008

Sri Redjeki Hartono, Hukum Ekonomi Indonesia, Malang : Bayumedia Publising, 2007

Sudikno Mertokusumo, Mengenal Hukum: Suatu Pengantar, Yogyakarta: Universitas Atma Jaya, 2010

Soerjono Soekanto, Pengantar Penelitian Hukum, Cet.3. - Jakarta: Penerbit Universitas Indonesia (UI-Press), 1986

Soerjono Soekanto \& Sri Mamuji, Penelitian Hukum Normatif, Ed.1.Cet.5, Jakarta: RajaGrafindo Persada, 2001

Sunariyah, Pengantar Pengetahuan Pasar Modal, Yogyakarta: Sekolah Tinggi Ilmu Manajemen YKPN, 2011

Suteki, Disertasi-Rekonstruksi Politik Hukum Tentang Hak Menguasai Negara Atas Sumber Daya Air Berbasis Nilai Keadilan Sosial, PDIH, UNDIP,2008

Suteki-Taufani, Metodologi Penelitian Hukum (Filsafat,Teori dan Praktik), Raja Grafindo Persada,Depok, 2018 
T. Mulya Lubis dan Richard M. Buxbaum, Peranan Hukum Dalam Perekonomian di Negara Berkembang, ed.1 - Jakarta: Yayasan Obor Indonesia, 1986

H.Salim HS, Penerapan Teori Hukum pada Penelitian Disertasi dan Tesis, KDT, Rajawali Pers Depok, 2017

Keputusan Menteri Keuangan RI No.1548/KMK/90 tentang Peraturan Pasar Modal.

\section{Undang-Undang:}

Undang-Undang Dasar Republik Indonesia 1945

Undang-Undang Nomor 25 Tahun 2007, Tentang Penanaman Modal

Undang-Undang Nomor 30 Tahun 2009, Tentang Ketenagalistrikan

Perpres No.76 Tahun 2007 (Kriteria Usaha Tertutup \&Terbuka dengan Syarat)

Perpres No.77 Tahun 2007 (Daftar Usaha Tertutup \& Terbuka dengan Syarat)

Perpres No.16 Tahun 2012, Rencana Umum Penanaman Modal

Perpres No.36 Tahun 2010 (DNI 2010)

Perpres No. 39 Tahun 2014 (DNI 2014)

Perpres No.44 Tahun 2016 (DNI 2016)

Perka BKPM, Nomor 1 Tahun 2017 